\title{
Pollen morphology of the genus Eremanthus Less. (Vernonieae, Asteraceae)
}

\author{
Benoit Loeuille ${ }^{1}$, Raquel Maria Batista Souza-Souza ${ }^{2}$, Vanessa Holanda Righetti Abreu²,
} Cláudia Barbieri Ferreira Mendonça ${ }^{2}$ and Vania Gonçalves-Esteves ${ }^{2,3}$

Recebido em 2/10/2011. Aceito em 7/11/2011

\begin{abstract}
RESUMO
(Morfologia polínica de espécies do gênero Eremanthus Less. (Vernonieae, Asteraceae)). Com a finalidade de avaliar a importância da morfologia polínica para a taxonomia de Eremanthus (Vernonieae, Asteraceae) em nível genérico e infragenérico e fornecer dados adicionais para a sua reconstrução filogenética, os grãos de pólen de 20 das 23 espécies do gênero foram examinados usando a microscopia de luz e eletrônica de varredura. Os grãos de pólen foram acetolisados, medidos, descritos e ilustrados sob microscópio de luz. Para a análise em microscópio eletrônico de varredura foram utilizados grãos de pólen com e/ou sem tratamento químico. As espécies apresentaram grãos de pólen isopolares, oblato-esferoidais, na maioria dos táxons, mais raramente prolato-esferoidais ou suboblatos, âmbito subtriangular, tricolporados e subechinolofados. A variação entre os caracteres quantitativos não se correlacionam com a subdivisão macromorfológica do gênero nem com os limites genéricos ou específicos.
\end{abstract}

Palavras-chave: Lychnophorinae, Compositae, taxonomia, palinologia

\begin{abstract}
(Pollen morphology of the genus Eremanthus Less. (Vernonieae, Asteraceae)). In order to evaluate the significance of the pollen morphology for generic and infrageneric taxonomy of the genus Eremanthus (Vernonieae, Asteraceae), and to provide additional data for its phylogenetic reconstruction, the pollen of 20 of the 23 species of the genus was examined using light and scanning electron microscopy. Acetolysed pollen grains were measured, described, and illustrated using light microscopy, while non-acetolysed pollen grains were analyzed using scanning electron microscopy. Pollen grains of these species are isopolar, oblate-spheroidal in most of the species, more rarely prolate spheroidal or suboblate, subtriangular amb, tricolporate and subechinolophate. The variation among quantitative characters does not correlate with the macromorphological subdivision of the genus or with the generic or specific limits.
\end{abstract}

Key words: Lychnophorinae, Compositae, taxonomy, palynology

\section{Introduction}

The tribe Vernonieae Cass. (Asteraceae) contains c. 1500 species distributed mostly in the tropical parts of the world with two major centers of diversification: southeastern Brazil and the central region of Africa (Robinson 1999, 2006/2007; Keeley \& Robinson 2009). The 129 genera are placed into 21 subtribes mainly defined by their inflorescence pattern, pollen morphology, chemical composition and chromosome number (Keeley \& Robinson 2009). Lychnophorinae is one of the biggest subtribes of Vernonieae, and includes ca. 100 species (11 genera) from the cerrado and campos rupestres of Brazil. This subtribe is defined by the lack of enlarged nodes or sclerified cells at the base of the styles, usually the extensive presence of a pubescence of T-shaped hairs, presence of sclerified cells and lack of glands on the anther appendages (Robinson 1992, 1999, 2007; Keeley \& Robinson 2009).

Eremanthus, a genus of c. 23 species, endemic to Brazil, is a typical element of the cerrado and campo rupestre floras (Keeley \& Robinson 2009). Robinson (1980) excluded herbaceous elements from Eremanthus and MacLeish (1984, 1987) recircumscribed the genus synonymising Vanillosmopsis (with deciduous inner pappus setae) under Eremanthus (with persistent inner pappus setae) and transferring nine species from Eremanthus to Vernonia. Robinson (1999) restricted the concept of Vernonia to North American taxa, and therefore had to reintegrate five of the latter excluded species into Eremanthus-E. crotonoides (DC.) MacLeish, E. leucodendron Mattf., E. mollis Sch. Bip., E. pabstii G. M.

\footnotetext{
Universidade de São Paulo, Instituto de Biociências, Departamento de Botânica, São Paulo, SP, Brazil

2 Universidade Federal de Rio de Janeiro, Museu Nacional, Departamento de Botânica, Rio de Janeiro, RJ, Brazil

Author for correspondence: esteves.vr@gmail.com
} 
Barroso and E. veadeiroensis H. Rob.-without specific morphological investigations. The narrower concept of Eremanthus, i.e., including Vanillosmopsis but not Paralychnophora (MacLeish 1987, Hind 2000), is here followed (for a different point of view, see Robinson 1997, 1999, 2006/2007).

Pollen characters of Asteraceae have been shown to be particularly variable and form useful patterns in the context of phylogenies. Such patterns could be used to support hypotheses of relationships, or provide diagnostic characters for groups at different levels (Wortley et al. 2007, Wortley et al. 2008, Blackmore et al. 2009). Blackmore et al. (2009) noticed that Vernonieae provides an example where a large number of pollen characters are congruent with the relationships presented in the Asteraceae supertree (Funk et al. 2005). Blackmore et al. (2009) provide putative synapomorphies for groups, most of them concerning African clades. Vernonieae pollen grains are usually lophate or sublophate, tricolporate or triporate, with either a continuous or discontinuous punctate or micropunctate tectum, and are with or without spines (Keeley $\&$ Robinson 2009; for a detailed description see Blackmore et al. 2009). The large pollen diversity of the tribe has been used extensively in taxonomic delimitations at generic and subtribal levels (Jones 1979, 1981, Bolick \& Keeley 1994; Keeley \& Robinson 2009). Kingham (1976) created six pollen Types (I-VI) for the tribe, based on the study of 85 species (mostly African). Keeley and Jones $(1977,1979)$ also identified six basic Types (A-F) to which additional variations have been added (Robinson 1999). Currently, ten pollen Types are recognised for the tribes (Dematteis \& Pire 2008). Using mainly the classification of Keeley and Jones, several authors have analysed and described pollen grains of Vernonieae, mostly of Vernonia s.l. (Keeley \& Jones 1977, 1979; Jones 1979, 1981; Robinson 1987a,b,c, 1988a,b,c, 1990; Skvarla et al. 2005; Mendonça \& Gonçalves-Esteves 2000; Mendonça et al. 2007a,b,c, 2009, 2010; Dematteis \& Pire 2008; Angulo \& Dematteis 2010).

The pollen grains of Lychnophorinae are tricolporate, echinate, sublophate with a perforated tectum continuous between colpi (Type "A") (Robinson 1992, 1999; Keeley \& Robinson 2009). The endoaperture is usually lalongate (Peçanha et al. 2008). The Type "A" pollen is considered a reversion from more strongly lophate ancestors in the Vernonieae, but it is nevertheless one of the most common forms in the tribe and is consistent in many groups such as the Piptocarphinae, Vernonia s.s. and Vernonanthura (Robinson 1990, 1992, 1999). Robinson (1999) suggested that due to common reversion of lophate pollen to Type "A", co-occurrence in different groups of the Vernonieae may have little phylogenetic significance.

The pollen Type of Eremanthus was initially described by Stix (1960) (based on E. glomerulatus Less. and E. polycephalus (DC.) MacLeish) as Lychnophora-type, and latter called Type "A" by Keeley and Jones (1979). Kingham (1976) assigned the pollen of E. crotonoides (as Vernonia crotonoi- des DC.) to his category VI: grains spherical, tricolporate, micropunctate, subechinolophate tending to echinate. Peçanha et al. (2008) described pollen grains of Paralychnophora bicolor (DC.) MacLeish (as E. bicolor (DC.) Baker) and E. erythropappus (DC.) MacLeish (as Vanillosmopsis erythropappa (DC.) Baker). This study revealed some interesting variation of the exine pattern at the generic level: Paralychnophora having a sublophate exine and Eremanthus a subechinolophate one. Peçanha et al. (2008) concluded that their data do not support the inclusion of Vanillosmopsis in Eremanthus (inclusion made by MacLeish in 1987). Such conclusion however cannot be considered valid, since they actually compared pollen grains of Paralychnophora with Eremanthus subg. Vanillosmopsis MacLeish, and not the latter with E. subg. Eremanthus Sch. Bip. as intended.

The present study aimed to conduct a comprehensive examination of the pollen morphology in the genus Eremanthus, using LM and SEM, with almost complete species coverage, in order to evaluate the significance of this structure for generic and infrageneric taxonomy and to provide additional data for the phylogenetic reconstruction.

\section{Materials and methods}

Pollen grains of 20 species of Eremanthus were examined (see Appendix). The samples were obtained from anthers of flower buds from specimen kept at the herbaria ESA, HRB, HUEFS, IBGE, MBM, SP, SPF, UB and UEC; acronyms according to Holmgren et al. (1990).

The terminology used for descriptions follows Punt et al. (2007), taking into consideration size, form, number of apertures and the ornamentation of the sexine. For the light microscopy (LM) study, the pollen grains were photomicrographed with a Sony Cyber-shot DSC-W7 digital camera coupled with a Zeiss Axiostar Plus microscope. For scanning electron microscopy (SEM), acetolysed and non-acetolysed pollen samples were placed on aluminium stubs covered with carbon tape and sputter-coated with a thin layer of gold palladium (c. $150 \AA$ ). The samples were analysed using a ZEISS DS M960 microscope at Laboratório de Ultraestrutura Celular Hertha Meyer, Inst. de Biofísica (UFRJ) and a JEOL JSM-5800 microscope at Departamento de Invertebrados do Museu Nacional (UFRJ).

Pollen grains were prepared for light microscopy by the acetolysis method of Erdtman (1952), modified by Melhem et al. (2003). Measurements in equatorial view ( $\mathrm{PD}=$ polar diameter and $\mathrm{ED}=$ equatorial diameter) were randomly taken on 25 pollen grains per sample. Measurements of equatorial diameter from polar view (EDPV) and apocolpus were randomly taken on 10 pollen grains distributed on, at least, three different slides.

Statistical procedures were carried out, calculating the arithmetic mean $\left({ }_{\mathrm{x}}\right)$; the standard deviation of the mean $\left(\mathrm{SD}_{\mathrm{X}}\right)$, the mean deviation $\left(\mathrm{S}_{\mathrm{X}}\right)$, the coefficient of variation (CV\%), the confidence interval at $95 \%$ and the variation 
range. For the measurements of the other characteristics, such as endoapertures size, layers of exine and pollen grain diameters of comparison material, the arithmetic mean of 10 measurements were calculated randomly chosen from, at least, three different slides (Salgado-Labouriau et al. 1965; Salgado-Labouriau 1973).

\section{Results}

The palynological description has been organised according to the following characteristics: size, polarity, shape, apertures and exine surface. The results of the measurements are summarized in Tab. 1-3, Fig. 1-5.

\section{Polarity, size and shape}

Pollen grains are isopolar, large, medium sized only in E. auriculatus (Fig. 1D), E. capitatus, E. erythropappus, E. polycephalus, E. seidelii and E. veadeiroensis, oblate spheroidal in most species, prolate spheroidal in $E$. argenteus and $E$. veadeiroensis, suboblate in E. uniflorus, subtriangular amb, small polar area in most species, very small in E. pohlii and large in E. argenteus and E. auriculatus (Tab. 1,2).

\section{Apertures}

Pollen grains are 3-colporate; colpus long (values range from $23.9 \mu \mathrm{m}$ in E. auriculatus and E. capitatus to $33 \mu \mathrm{m}$ in E. elaeagnus); colpus wide, width varying from $4.6 \mu \mathrm{m}(E$. mattogrossensis) to $9.1 \mu \mathrm{m}$ and $9.6 \mu \mathrm{m}$ (E. elaeagnus and E. glomerulatus). The endoapertures are lalongate (smallest diameter: $1.6 \mu \mathrm{m}$ in E. mollis; largest one: $6.8 \mu \mathrm{m}$ in $E$. mattogrossensis) (Tab. 3). Some species have endoapertures with a median constriction, as in E. capitatus (Fig. 1I), E. crotonoides (Fig. 2C), E. erythropappus (Fig. 2I), E. graciellae (Fig. 3E), E. leucodendron (Fig. 3K), E. polycephallus (Fig. $4 \mathrm{H}$ ), E. rondoniensis (Fig. 4K), E. uniflorus (Fig. 5F).

\section{Exine}

The exine is thick: values range from 5.1 (E. rondoniensis) to $13.5 \mathrm{~mm}$ (E. argenteus). The sexine is subechinolophate, muri tall, sinuous, densely microperfurate at the base of muri and one microperfuration at the base of spine. The spines show variation in size: the longest spines were found in E. pohlii $(12.2 \mu \mathrm{m})($ Fig. $4 \mathrm{~F})$ and the shortest ones in $E$. veadeiroensis $(4 \mu \mathrm{m})(\mathrm{Fig} .5 \mathrm{H})$, the width of the spines ranges from 2 (E. veadeiroensis) to $7.4 \mu \mathrm{m}$ (E. incanus). The distance between the spines varies widely, ranging from 3.4 ( $E$. veadeiroensis) to $11.4,11.7$ and $11.8 \mathrm{~mm}$ (E. glomerulatus, E. pohlii and E. uniflorus, respectively). The sexine is always thicker than the nexine (Tab. 3).

\section{Discussion}

In the present study 20 species of Eremanthus were analysed ( $87 \%$ of the species), including all taxa placed by
Robinson (1999) in the genus (except Paralychnophora species). The pollen of Eremanthus is isopolar, oblate spheroidal in most of the species, more rarely prolate spheroidal or suboblate, subtriangular amb, tricolporate and subechinolophate, i.e., corresponding to Type «A». Many of the quantitative characters have some variability, however the results show considerable overlap between species. Therefore, it was not possible to construct a palynological key to identify the species or to define some pollen subtypes.

The pollen shape is the only qualitative character that varies in the genus. Eremanthus argenteus MacLeish \& H. Schumach. and E. veadeiroensis H. Rob. have prolate spheroidal pollen grains, the former belongs to the subg. Eremanthus and the latter was not included in Eremanthus by MacLeish $(1984,1987)$ because of its densely pubescent stems, loose inflorescence and a large number of florets per capitulum (8-11); these three characters are uncommon within the genus. Phylogenetic analyses based on molecular and morphological data (Loeuille 2011) have indicated that E. veadeiroensis is closely related to E. elaeagnus (Mart. ex DC.) Sch. Bip. of subg. Pseuderemanthus. The two species of subg. Pseuderemanthus (E. elaeagnus and E. seidelii MacLeish \& H. Schumach.) have, nonetheless, an oblate spheroidal pollen as the majority of the species. Eremanthus argenteus belongs to E. subg. Eremanthus sect. Synglomerulus MacLeish \& H. Schumach. characterised by its simple cyme synflorescence. The two others species of this section (E. auriculatus MacLeish \& H. Schumach. and E. cinctus Baker) have an oblate spheroidal pollen shape, not prolate spheroidal like E. argenteus.

The subg. Vanillosmopsis is composed of eight species, six of them are included in this study: Eremanthus capitatus (Spreng.) MacLeish, E. erythropappus (DC.) MacLeish, E. graciellae MacLeish \& H. Schumach., E. pohlii (Baker) MacLeish, E. polycephalus (DC.) MacLeish and E. uniflorus MacLeish \& H. Schumach. No palynological characters have been found to characterise this subgenus. Based on a macromorphological analysis, Loeuille et al. (in prep.) suggested that E. capitatus, E. graciellae and E. pohlii are conspecific. The quantitative characters vary conspicuously between the three species, a variation that encompasses the subgeneric categories, E. pohlii having more similar pollen grains of the species of subg. Eremanthus than of subg. Vanillosmopsis.

The results of phylogenetic analyses (Loeuille 2011) have indicated that E. crotonoides, E. leucodendron and E. pabstii are not closely related to the genus Eremanthus. Again, our palynological data did not show any difference between these species and the rest of the genus.

The presence of meaningless differences in pollen between closely related species of the tribe Vernonieae has already been documented. For instance, in the small genus Eirmocephala H. Rob., E. brachiata (Bentham ex Oersted) H. Rob. has a Type «D» and E. megaphylla (Hieron.) H. Rob. Type «A» (Robinson 1987b) pollen. A certain degree of instability of types is also found in Distephanus 
Table 1. Pollen characters $(\mu \mathrm{m})$ in equatorial view of Eremanthus species $(\mathrm{n}=25)$.

\begin{tabular}{|c|c|c|c|c|c|c|c|}
\hline \multirow[t]{2}{*}{ Species } & \multicolumn{3}{|c|}{$\mathrm{PD}$} & \multicolumn{3}{|c|}{$\mathrm{ED}$} & \multirow[t]{2}{*}{$\mathrm{PD} / \mathrm{ED}$} \\
\hline & Variation range & $\mathrm{X} \pm \mathrm{SD}_{\mathrm{X}}$ & IC (95\%) & Variation range & $\mathrm{X} \pm \mathrm{SD}_{\mathrm{x}}$ & IC (95\%) & \\
\hline E. argenteus & $47.5-57.5$ & $52.4 \pm 0.5$ & $51.4-53.4$ & $40.0-62.5$ & $51.6 \pm 0.9$ & $49.8-53.4$ & 1.01 \\
\hline E. auriculatus & $40.0-57.5$ & $45.0 \pm 0.7$ & $43.6-46.4$ & $42.5-52.5$ & $48.0 \pm 0.5$ & $47.0-49.0$ & 0.93 \\
\hline E. capitatus & $37.5-47.5$ & $41.6 \pm 0.5$ & $40.6-42.6$ & $35.0-50.0$ & $45.8 \pm 0.6$ & $44.6-47.0$ & 0.90 \\
\hline E. cinctus & $55.0-67.5$ & $61.2 \pm 0.5$ & $60.2-62.2$ & $61.8-72.5$ & $67.7 \pm 0.5$ & $66.7-68.7$ & 0.90 \\
\hline E. crotonoides & $42.5-52.5$ & $46.1+0.3$ & $45.5-46.7$ & $45.0-60.0$ & $51.1+0.5$ & $50.1-52.1$ & 0.90 \\
\hline E. elaeagnus & $47.5-55.5$ & $52.5 \pm 0.3$ & $51.9-53.1$ & $20.0-62.5$ & $55.9 \pm 0.5$ & $54.9-56.9$ & 0.93 \\
\hline E. erythropappus & $37.5-55.0$ & $44.8 \pm 0.7$ & $43.4-46.2$ & $42.5-57.5$ & $49.7 \pm 0.8$ & $48.1-51.3$ & 0.90 \\
\hline E. glomerulatus & $48.0-61.2$ & $53.7 \pm 0.6$ & $52.5-54.9$ & $52.5-61.2$ & $56.3 \pm 0.5$ & $55.3-57.3$ & 0.95 \\
\hline E. goyazensis & $47.5-55.0$ & $51.5 \pm 0.3$ & $50.9-52.1$ & $50.0-57.5$ & $52.9 \pm 0.3$ & $52.3-53.5$ & 0.97 \\
\hline E. graciellae & $45.0-50.0$ & $47.1 \pm 0.3$ & $46.4-47.8$ & $47.5-55.0$ & $50.6 \pm 0.4$ & $49.8-51.4$ & 0.93 \\
\hline E. incanus & $42.5-55.0$ & $47.4 \pm 0.6$ & $46.2-48.6$ & $47.5-57.5$ & $51.3 \pm 0.5$ & $50.3-52.3$ & 0.92 \\
\hline E. leucodendron & $47.5-55.0$ & $51.0 \pm 0.4$ & $50.2-51.8$ & $52.5-62.5$ & $56.2 \pm 0.4$ & $55.4-57.0$ & 0.90 \\
\hline E. mattogrossensis & $48.8-55.0$ & $52.2 \pm 0.4$ & $51.4-53.0$ & $50.0-57.5$ & $53.5 \pm 0.4$ & $52.7-54.3$ & 0.97 \\
\hline E. mollis & $50.0-60.0$ & $56.2 \pm 0.4$ & $55.4-57.0$ & $55.0-65.0$ & $61.6 \pm 0.5$ & $60.6-62.6$ & 0.91 \\
\hline E. pohlii & $52.5-62.5$ & $57.7 \pm 0.4$ & $56.9-58.5$ & $57.5-65.2$ & $61.6 \pm 0.4$ & $60.8-62.4$ & 0.93 \\
\hline E. polycephalus & $40.0-52.5$ & $46.0 \pm 0.5$ & $45.0-47.0$ & $46.2-53.8$ & $49.2 \pm 0.4$ & $48.4-50.0$ & 0.93 \\
\hline E. rondoniensis & $52.5-62.5$ & $57.7 \pm 0.6$ & $56.5-58.9$ & $57.5-67.5$ & $61.7 \pm 0.5$ & $60.7-62.7$ & 0.93 \\
\hline E. seidelii & $40.0-46.2$ & $43.2 \pm 0.3$ & $42.6-43.8$ & $45.0-50.0$ & $47.3 \pm 0.2$ & $46.9-47.7$ & 0.91 \\
\hline E. uniflorus & $42.5-50.0$ & $47.0 \pm 0.3$ & $46.4-47.6$ & $50.0-54.0$ & $53.9 \pm 0.5$ & $52.9-54.9$ & 0.87 \\
\hline E. veadeiroensis & $37.5-45.0$ & $41.2 \pm 0.4$ & $40.4-42.0$ & $35.0-40.0$ & $38.0 \pm 0.3$ & $37.4-38.6$ & 1.08 \\
\hline
\end{tabular}

$\mathrm{PD}$ - polar diameter; $\mathrm{ED}$ - equatorial diameter; $\mathrm{X}$ - means; $\mathrm{SD}_{\mathrm{X}}$ - standard deviations of the mean; $\mathrm{IC}$ - confidence interval

Table 2. Pollen characters $(\mu \mathrm{m})$ in polar view of Eremanthus species $(\mathrm{n}=10)$.

\begin{tabular}{|c|c|c|c|c|c|c|}
\hline \multirow[t]{2}{*}{ Species } & \multicolumn{2}{|c|}{ EDPV } & \multicolumn{2}{|c|}{ Apocolpus } & \multicolumn{2}{|c|}{ Polar area } \\
\hline & Variation range & $\mathrm{X}$ & Variation range & $\mathrm{X}$ & PAI & Size \\
\hline E. argenteus & $46.25-62.5$ & 55.8 & $27.5-32.5$ & 28.5 & 0.51 & large \\
\hline E. auriculatus & $45.0-50.0$ & 47.5 & $25.0-27.5$ & 25.2 & 0.53 & large \\
\hline E. capitatus & $42.5-47.5$ & 45.6 & $10.0-12.5$ & 11.5 & 0.25 & small \\
\hline E. cinctus & $60.0-70.0$ & 65.8 & $15.0-25.0$ & 19.5 & 0.29 & small \\
\hline E. crotonoides & $47.5-52.5$ & 51.2 & $20.0-25.0$ & 23.2 & 0.45 & small \\
\hline E. elaeagnus & $47.5-60.0$ & 54.1 & $10.0-20.0$ & 16.0 & 0.29 & small \\
\hline E. erythropappus & $42.5-53.8$ & 48.7 & $10.0-20.0$ & 13.0 & 0.26 & small \\
\hline E. glomerulatus & $47.5-60.0$ & 53.6 & $12.5-20.0$ & 17.7 & 0.33 & small \\
\hline E. goyazensis & $50.0-57.5$ & 53.0 & $12.5-17.5$ & 14.2 & 0.26 & small \\
\hline E. graciellae & $47.0-52.5$ & 49.4 & $10.0-15.0$ & 12.5 & 0.25 & small \\
\hline E. incanus & $46.25-51.2$ & 49.5 & $15.0-25.0$ & 20.0 & 0.40 & small \\
\hline E. leucodendron & $50.5-55.25$ & 53.8 & $12.5-20.0$ & 15.5 & 0.28 & small \\
\hline E. mattogrossensis & $47.5-55.0$ & 51.6 & $12.5-25.0$ & 20.5 & 0.39 & small \\
\hline E. mollis & $55.5-63.8$ & 59.7 & $22.5-30.0$ & 27.5 & 0.46 & small \\
\hline E. pohlii & $55.0-61.2$ & 59.6 & $12.5-17.5$ & 14.7 & 0.24 & very small \\
\hline E. polycephalus & $45.0-52.5$ & 49.6 & $20.0-25.0$ & 23.0 & 0.46 & small \\
\hline E. rondoniensis & $56.25-62.5$ & 59.1 & $15.0-25.0$ & 18.5 & 0.31 & small \\
\hline E. seidelii & $42.5-49.8$ & 46.0 & $12.5-15.0$ & 13.7 & 0.29 & small \\
\hline E. uniflorus & $49.75-57.5$ & 52.2 & $12.5-20.0$ & 15.5 & 0.29 & small \\
\hline E. veadeiroensis & $50.0-57.5$ & 51.7 & $12.5-17.5$ & 15.2 & 0.29 & small \\
\hline
\end{tabular}

EDPV - equatorial diameter in polar view; PAI - polar area index. 

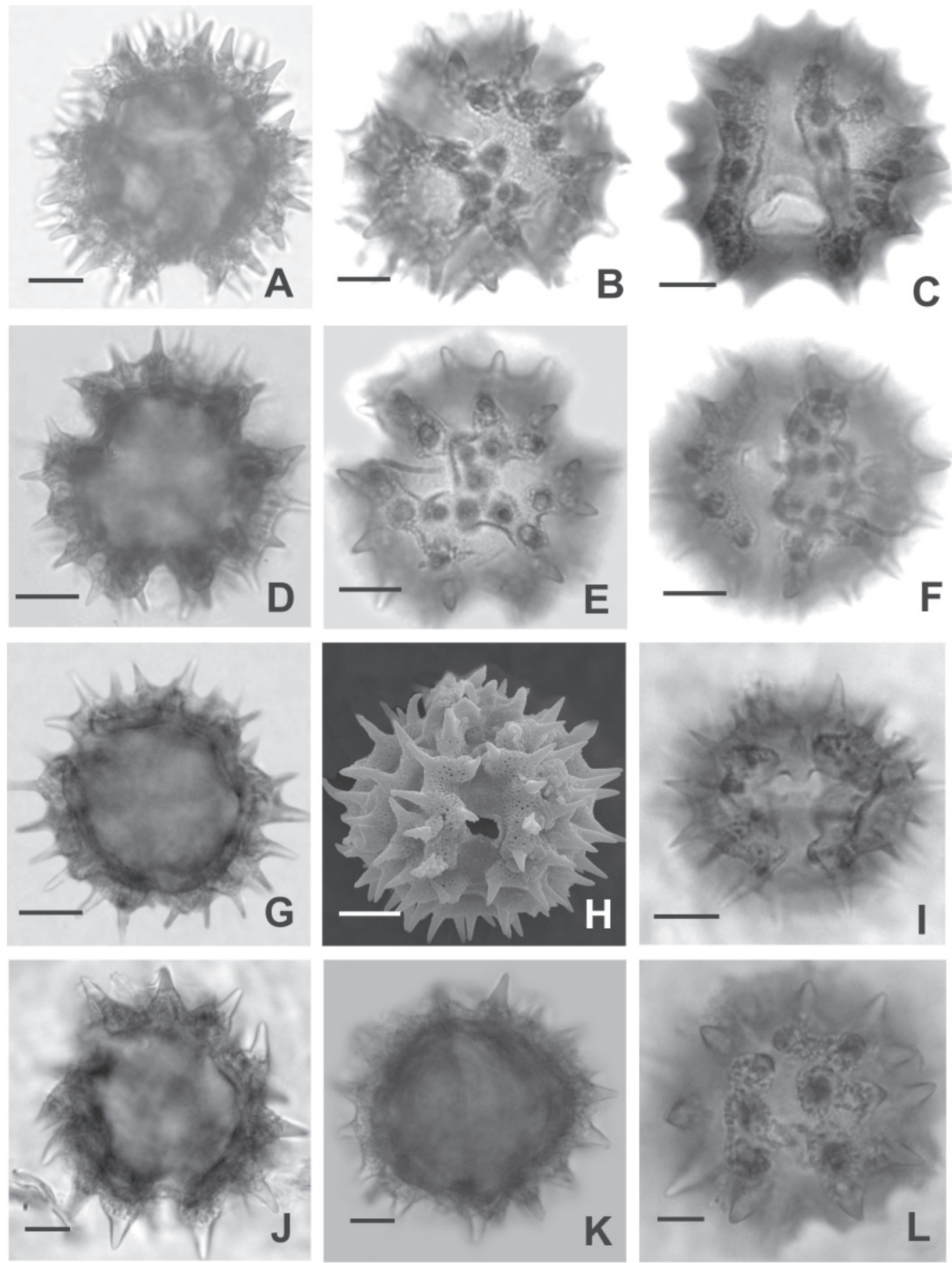

Figure 1. LM and SEM photomicrographs of the pollen grains of Eremanthus. A-C. E. argenteus - polar view: A. Cross section; B. Surface of apocolpium; C. Lateral view, aperture. D-F. E. auriculatus - polar view: D. Cross section; E. Surface of apocolpium; F. Equatorial view, aperture. G-I. E. capitatus - polar view: G. cross section; equatorial view: H. Surface of the aperture area (SEM); I. Aperture. J-L. E. cinctus - polar view: J. Cross section; equatorial view: K. Cross section; L. Aperture. Barras $=10 \mathrm{~mm}$. 

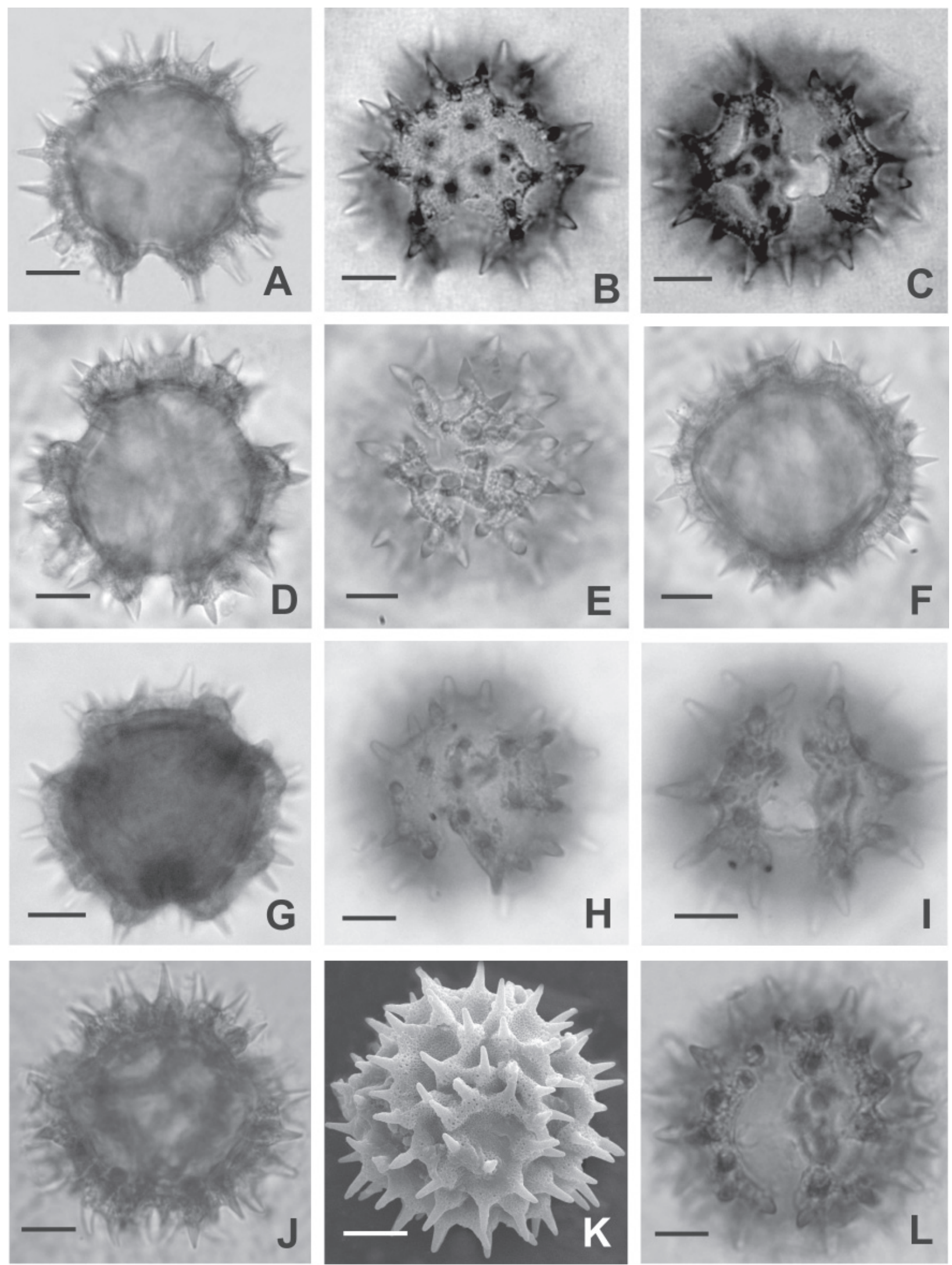

Figure 2. LM and SEM photomicrographs of the pollen grains of Eremanthus. A-C. E. crotonoides - polar view: A. Cross section; B. Surface of apocolpium; C. Lateral view, aperture. D-F. E. elaeagnus - polar view: D. Cross section; E. Surface of apocolpium; F. Equatorial view, cross section and aperture. G-I. E. erythropappus polar view: G. Cross section; H. Surface of apocolpium; equatorial view: I. Aperture. J-L. E. glomerulatus - polar view: J. Cross section; equatorial view: K. Surface of mesocolpium (SEM); L. Aperture. Barras $=10 \mathrm{~mm}$. 

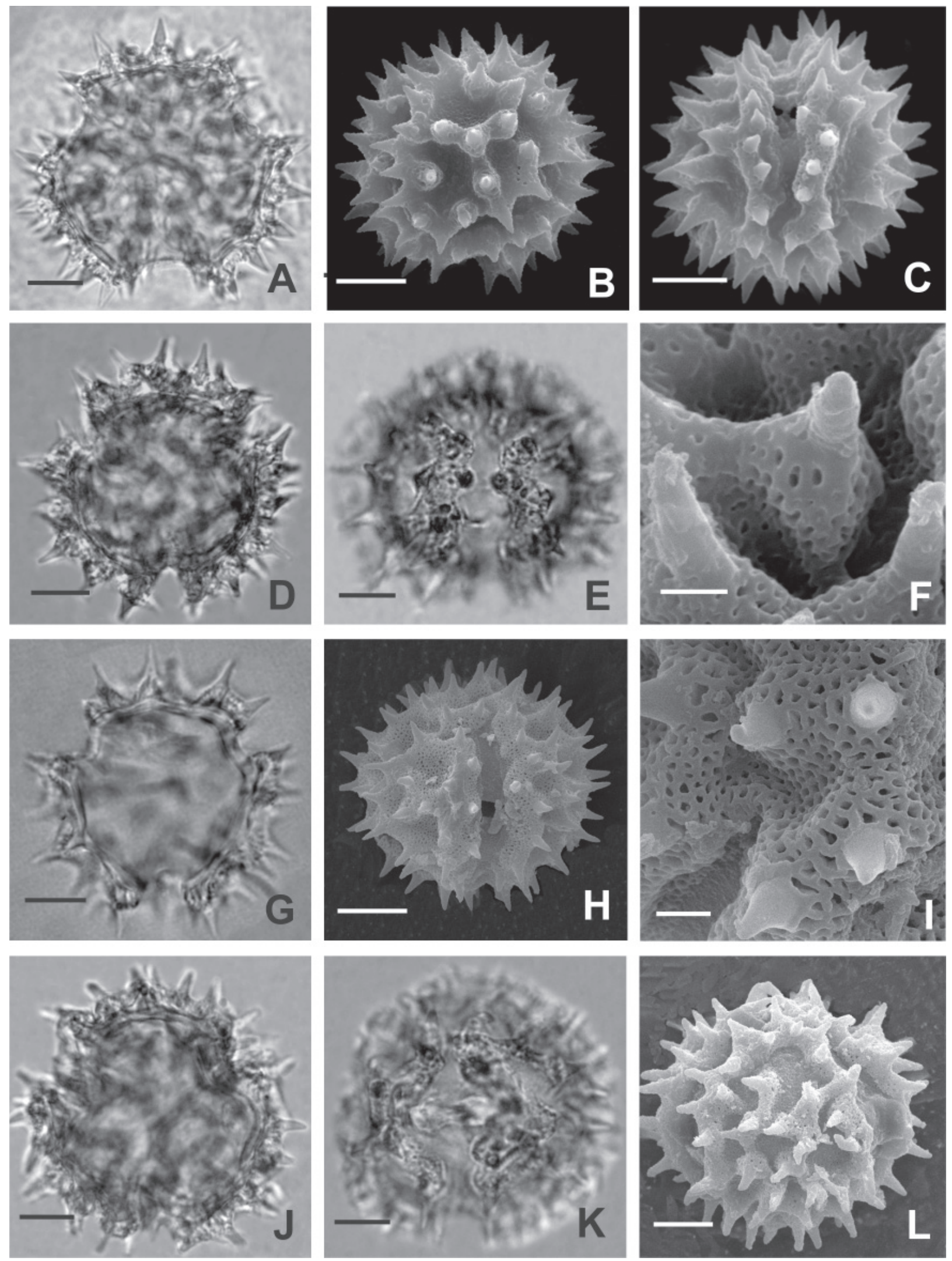

Figure 3. LM and SEM photomicrographs of the pollen grains of Eremanthus. A-C. E. goyazensis - polar view: A. Cross section; equatorial view: B. Surface of apocolpium (SEM); C. Aperture (SEM). D-F. E. graciellae - polar view: D. Cross section; equatorial view: E. Aperture; F. Detail of surface (SEM). G-I. E. incanus - polar view: G. Cross section; equatorial view: H. Aperture (SEM), I. Detail of surface (SEM). J-L. E. leucodendron - polar view: J. Cross section; equatorial view: K. Aperture; L. Surface of mesocolpium (SEM). Barras $=10 \mathrm{~mm}$; F, I = $2 \mathrm{~mm}$. 

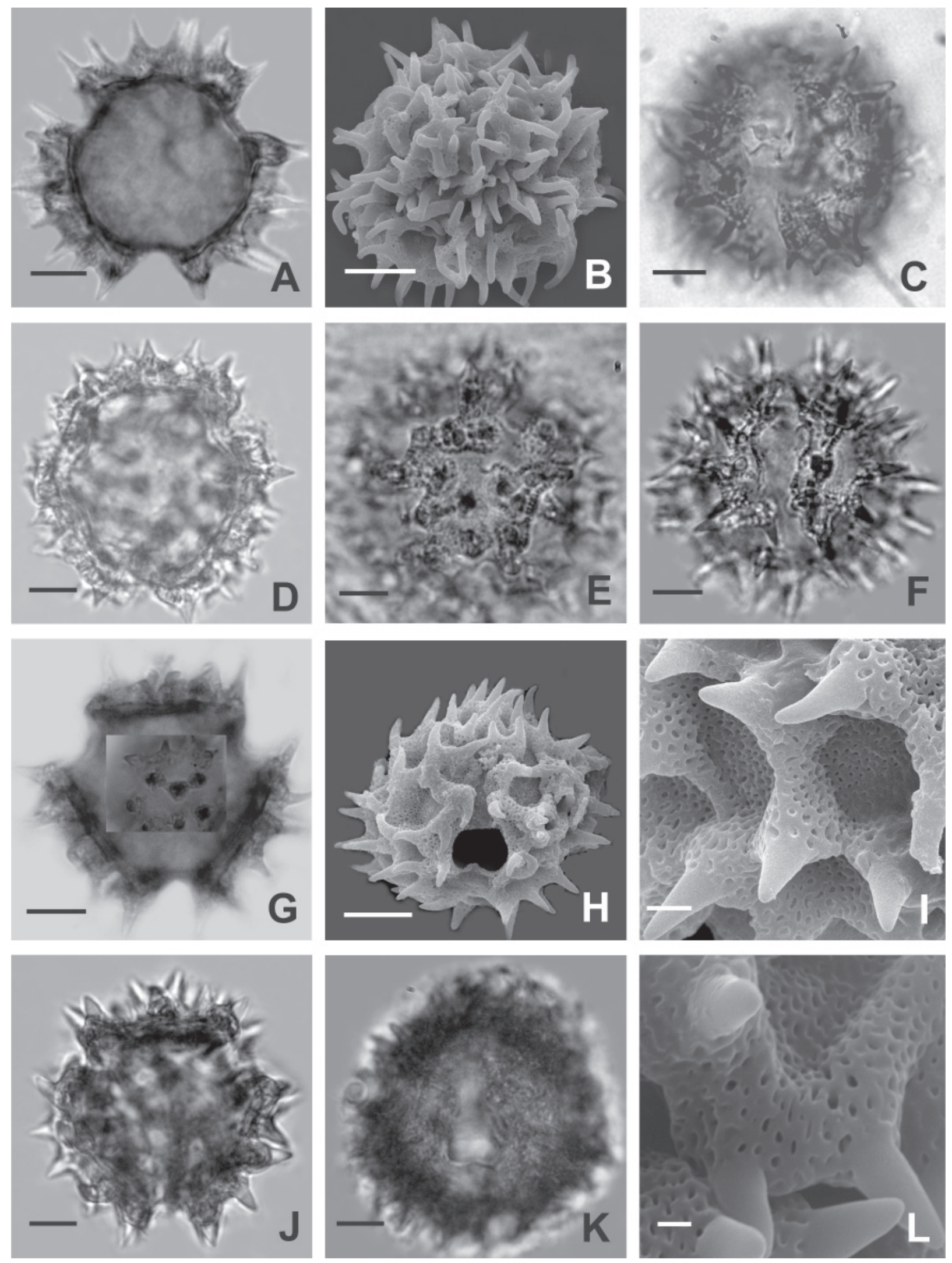

Figure 4. LM and SEM photomicrographs of the pollen grains of Eremanthus. A-C. E. mattogrossensis - polar view: A. Cross section; B. Surface of apocolpium (SEM); C. Equatorial view, aperture. D-F. E. pohlii - polar view: D. Cross section; E. Surface of apocolpium; F. Equatorial view, aperture. G-I. E. polycephalus - polar view: G. Cross section; equatorial view: H. Aperture; polar view: I. Detail of surface (SEM). J-L. E. rondoniensis - polar view: J. Cross section; equatorial view: K. Aperture; L. Detail of surface (SEM). Barras $=10 \mathrm{~mm} ; \mathrm{I}=2 \mathrm{~mm} ; \mathrm{L}=1 \mathrm{~mm}$. 

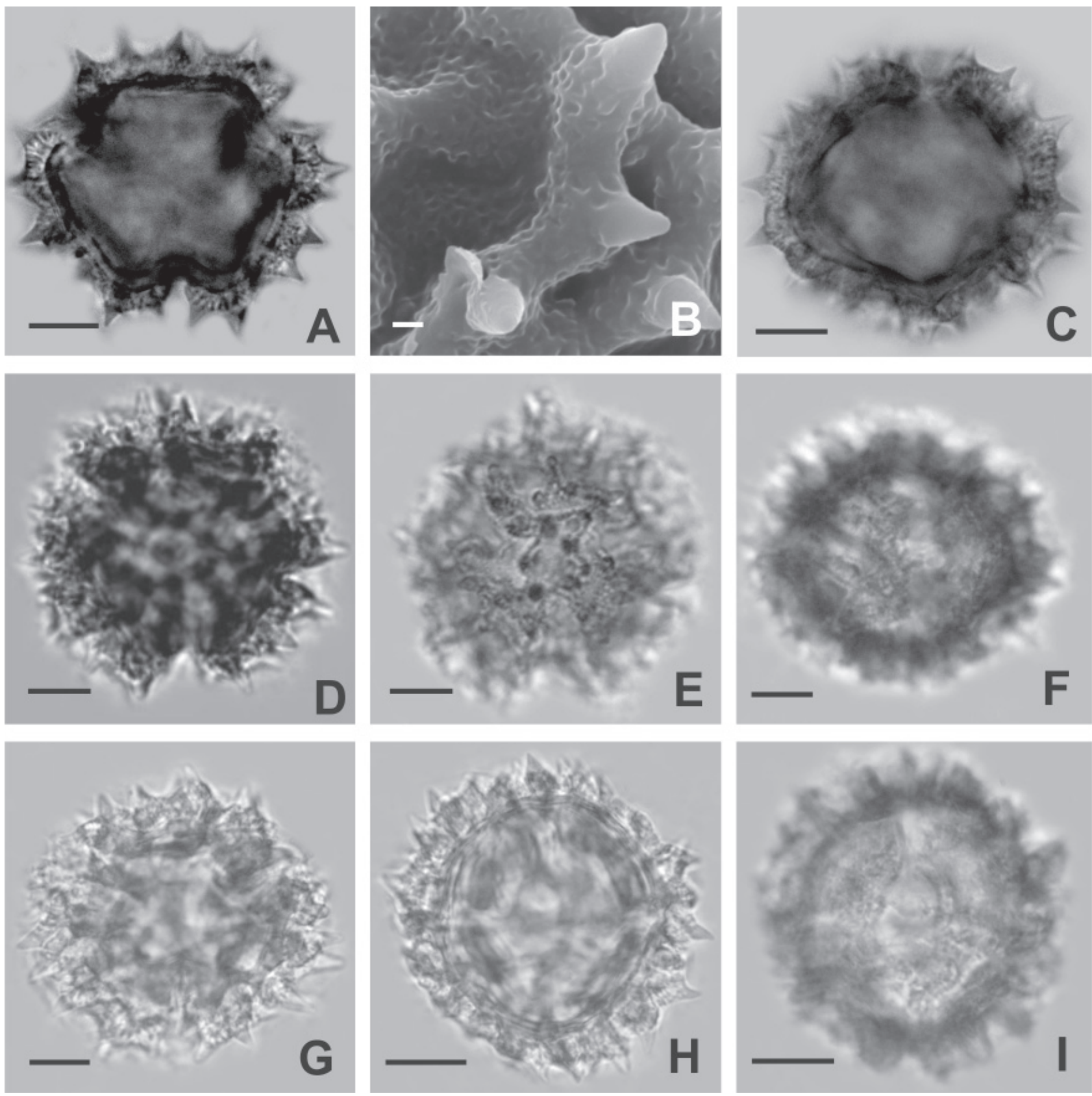

Figure 5. LM and SEM photomicrographs of the pollen grains of Eremanthus. A-C. E. seidelii - polar view: A. Cross section; B. Detail of surface (SEM); C. Equatorial view, aperture. D-F. E. uniflorus - polar view: D. Cross section; E. Surface of apocolpium; F. Equatorial view, aperture. G-I. E. veadeiroensis - polar view: G. Cross section; equatorial view: H. Cross section; I. Aperture. Barras $=10 \mathrm{~mm}$.

Cass. (Robinson \& Kahn 1986). The case of Eremanthus is slightly different because the only variation is found in the quantitative characters, which are usually more difficult to interpret. The pollen grains of the species here analysed are typically subechinolophate and not sublophate, i.e., not Type «A» sensu Keeley \& Jones (1979) (echinate to sublophate, continuous and microperforate tectum, spines on the ridges of sublophate grains). Therefore one might consider that the Eremanthus species are a modified Type «A» (subechinolophate).
Blackmore (2000) emphasizes the importance of determining at which taxonomic hierarchy level the pollen data are most useful. The present study clearly demonstrates that the pollen morphology is taxonomically uninformative at the specific level for the genus Eremanthus and probably to a certain degree at the generic level in the subtribe Lychnophorinae. Therefore, the general idea that pollen morphology is significant in delimitating at specific and generic levels into the entire tribe Vernonieae (Angulo \& Dematteis 2010) has to be rectified; the situation in some 
Table 3. Pollen measurements $(\mu \mathrm{m})$ of endoapertures and exine layers of Eremanthus species $(\mathrm{n}=10)$.

\begin{tabular}{|c|c|c|c|c|c|c|c|c|c|c|c|}
\hline \multirow[t]{2}{*}{ Species } & \multicolumn{2}{|c|}{ Colpus } & \multicolumn{2}{|c|}{ Endoaperture } & \multicolumn{4}{|c|}{ Exine layers } & \multicolumn{3}{|c|}{ Spine } \\
\hline & length & width & length & width & Exine & Nexine & Sexine ${ }^{*}$ & Sexine $e^{* *}$ & length & width & distance $e^{* * *}$ \\
\hline E. argenteus & 25.6 & 5.5 & 2.8 & 11.3 & 13.5 & 1.0 & 12.5 & 1.1 & 11.4 & 6.4 & 10.7 \\
\hline E. auriculatus & 23.9 & 5.2 & 4.4 & 5.4 & 9.6 & 1.0 & 8.6 & 1.0 & 7.6 & 5.2 & 7.9 \\
\hline E. capitatus & 23.9 & 5.0 & 4.2 & 5.0 & 10.8 & 1.0 & 9.8 & 1.0 & 8.8 & 4.4 & 8.6 \\
\hline E. cinctus & 29.4 & 7.7 & 4.6 & 10.9 & 7.2 & 0.9 & 6.3 & 0.9 & 5.4 & 3.7 & 6.1 \\
\hline E. crotonoides & 24.3 & 6.1 & 5.7 & 26.1 & 11.9 & 0.9 & 11.0 & 0.9 & 10.1 & 4.9 & 9.9 \\
\hline E. elaeagnus & 33.0 & 9.1 & 4.0 & 14.9 & 12.1 & 1.0 & 11.1 & 1.6 & 9.5 & 6.9 & 10.5 \\
\hline E. erythropappus & 28.9 & 7.1 & 5.8 & 7.1 & 12.3 & 1.8 & 10.5 & 2.1 & 8.4 & 5.0 & 8.3 \\
\hline E. glomerulatus & 31.3 & 9.6 & 4.9 & 9.6 & 13.2 & 1.8 & 11.4 & 1.4 & 10.0 & 6.0 & 11.8 \\
\hline E. goyazensis & 29.4 & 7.2 & 5.7 & 11.2 & 12.3 & 1.0 & 11.3 & 1.2 & 10.1 & 5.6 & 10.7 \\
\hline E. graciellae & 28.8 & 6.1 & 4.2 & 9.9 & 11.8 & 1.1 & 10.7 & 1.3 & 9.4 & 5.5 & 10.2 \\
\hline E. incanus & 25.5 & 5.2 & 4.1 & 8.7 & 12.5 & 1.2 & 11.3 & 1.2 & 10.3 & 7.4 & 10.7 \\
\hline E. leucodendron & 32.1 & 7.3 & 5.9 & 12.4 & 12.6 & 1.1 & 11.5 & 1.2 & 10.3 & 5.9 & 10.7 \\
\hline E. mattogrossensis & 28.3 & 4.6 & 6.8 & 7.5 & 10.4 & 1.1 & 9.3 & 1.0 & 8.3 & 4.5 & 7.7 \\
\hline E. mollis & 23.2 & 5.3 & 1.6 & 12.5 & 11.0 & 1.0 & 10.0 & 1.0 & 9.0 & 5.4 & 5.9 \\
\hline E. pohlii & 31.0 & 6.4 & 5.2 & 10.7 & 14.3 & 1.0 & 13.3 & 1.1 & 12.2 & 6.3 & 11.7 \\
\hline E. polycephalus & 24.6 & 5.8 & 4.2 & 11.0 & 11.5 & 1.0 & 10.5 & 1.0 & 9.5 & 5.9 & 8.9 \\
\hline E. rondoniensis & 31.2 & 6.7 & 6.1 & 11.7 & 5.1 & 0.9 & 4.2 & 0.9 & 4.3 & 2.8 & 4.0 \\
\hline E. seidelii & 27.3 & 5.3 & 4.1 & 8.1 & 10.2 & 1.0 & 9.2 & 1.0 & 8.2 & 4.9 & 9.0 \\
\hline E. uniflorus & 28.3 & 5.9 & 4.0 & 9.7 & 12.6 & 1.3 & 11.3 & 1.0 & 10.3 & 5.6 & 11.4 \\
\hline E. veadeiroensis & 25.5 & 5.2 & 4.1 & 13.8 & 6.0 & 1.0 & 5.0 & 1.0 & 4.0 & 2.0 & 3.4 \\
\hline
\end{tabular}

Sexine ${ }^{*}$ - total sexine; sexine ${ }^{* *}$ - sexine between spines; distance ${ }^{* * *}$ - distance between spines

groups (especially the Lepidaploa complex) could not be used as a general rule in the tribe.

The absence of variable qualitative characters and the fact that quantitative characters show a high level of homoplasy limit greatly the use of palynological data to reconstruct the phylogeny of the subtribe Lychnophorinae. Keeley \& Robinson (2009) arrived at a similar conclusion for Vernonieae. Nonetheless, because Peçanha et al. (2008) found sublophate pollen in Paralychnophora bicolor, it would be valuable to analyse the pollen grains of more species of that genus and of other genera of the subtribe Lychnophorinae to evaluate how frequent the sublophate pattern occurs and if it could be used in a systematic context.

\section{Conclusions}

Pollen Type "A" is present in all the species of the genus Eremanthus. No qualitative variation has been found in different species and the variation of quantitative characters does not correlate with the macromorphological subdivision of the genus at the generic or specific limits. These results indicate that palynological data might not be variable enough to be relevant in the delimitation at the specific level and probably at the generic level in the subtribe Lychnophorinae.

\section{Acknowledgements}

The authors acknowledge Noêmia Rodrigues Gonçalves (Lab. de Ultraestrutura Celular do Inst. de Biofísica da Univ. Federal do Rio de Janeiro) for the technical support, and FAPERJ (Proc. E-26/110.953/09, supplies for the lab and grant for and fellowship support to the second author), $\mathrm{CNPq}$ (fellowship supports for the first, third and last authors), and CAPES (fellowship support to the last author) for the financial support.

\section{Specimens investigated}

Eremanthus argenteus MacLeish \& H. Schumach. BRAZIL, GoIÁs, Teresina de Goiás, Chapada dos Veadeiros, Souza 24698 (ESA).

E. auriculatus MacLeish \& H. Schumach. BRAZIL, GoIÁs, Alto Paraíso, Chapada dos Veadeiros. Loeuille 279 (SPF).

E. capitatus (Spreng) MacLeish. BRAZIL: BAHIA, Salvador, Metropolitan Park Pituaçu, Teles 35 (SPF).

E. cinctus Baker. BRAZIL: GoIÁs, Chapadão do Céu, National Park of Emas, Batalha 3038 (SPF).

E. crotonoides Sch. Bip. BRAZIL: MinAs GerAIs, Santa Bárbara, Serra do Caraça, Pirani 338 (SPF).

E. elaeagnus (Mart. ex DC.) Sch. Bip. BRAZIL: Minas Gerais, Diamantina, road to Conselheiro Mata, Arbo 4385 (SPF).

E. erythropappus (DC.) MacLeish. BRAZIL: Minas GERAIS, Datas, Morro do Coco, Mello-Silva CFCR 7997 (SPF).

E. glomerulatus Less. BRAZIL: BAHIA, Abaíra, Catolés, Mata do Bem Querer, Ganev 271 (SPF). 
E. goyazensis (Gardner) Sch. Bip. BRAZIL: GoIÁs, Alto Paraíso, Chapada dos Veadeiros, Moraes 644 (UEC).

E. graciellae MacLeish \& H. Schumach. BRAZIL: BAHIA, Correntina, Biological Reserve Fazenda Jatobá, Aparecida da Silva 1527 (UB).

E. incanus (Less.) Less. BRAZIL: MinAs GeraIs, Diamantina, Cachoeira da Sentinela, Stehmann 2683 (ESA).

E. leucodendron Mattf. BRAZIL: BAHIA, Rio de Contas, Pico de Itabira, Harley PCD 4277 (SPF).

E. mattogrossensis Kuntze. BRAZIL: São PAulo, Pedregulho, Estreito, Sasaki 527 (SPF).

E. mollis Sch. Bip. BRAZIL: Minas GeraIs, Capitólio, Represa de Furnas, Vichnewski s.n. (UEC n 19067).

E. pohlii (Baker) MacLeish. BRAZIL: Minas GeraIs, São Gonçalo do Abaeté, Hatschbach, G. 67936 (MBM).

E. polycephalus (DC.) MacLeish. BRAZIL: Minas Gerais, Grão Mogol, estrada para Virgem da Lapa, Souza 25838 (SPF).

E. rondoniensis MacLeish \& H. Schumach. BRAZIL: MATo Grosso, Arenápolis, Chapada dos Parecis, Hatschbach 62692 (MBM).

E. seidelii MacLeish \& H. Schumach. BRAZIL: Minas GeraIs, Formiga, Schumacher 3027 (UEC).

E. uniflorus MacLeish \& H. Schumach. BRAZIL: Goıás, Alto Paraíso, National Park Chapada dos Veadeiros, Mendonça 2246 (IBGE).

E. veadeiroensis H. Rob. BRAZIL: GoIÁs, Alto Paraíso, Chapada dos Veadeiros, King 8831 (UB).

\section{References}

Angulo, M.B. \& Dematteis, M. 2010. Pollen morphology of the South American genus Lessingianthus (Vernonieae, Asteraceae) and its taxonomic implications. Grana 49: 12-25.

Blackmore, S. 2000. The palynological compass: the contribution of palynology to systematics. Pp. 161-177. In Nordenstam, B. El-Ghazaly, G. \& Kassas, M. (Eds.). Plant Systematics for the 21st Century London, Portland Press.

Blackmore, S.; Wortley, A.H.; Skvarla, J.J. \& Robinson, H. 2009. Evolution of pollen in the Compositae. Pp. 101-130. In Funk, V.A.; Susanna, A.; Stuessy, T.F. \& Bayer, R.J. (Eds), Systematics, evolution and biogeography of Compositae. Wien, IAPT.

Bolick, M.R. \& Keeley, S.C. 1994. Pollen morphology and classification of the Vernonieae. Acta Botanica Gallica 141: 279-284.

Dematteis, M. \& Pire, S.M. 2008. Pollen morphology of some species of Vernonia s. l. (Vernonieae, Asteraceae) from Argentina and Paraguay. Grana 47: 117-129.

Erdtman, G. 1952. Pollen morphology and plant taxonomy Angiosperms. Stockholm, Almqvisit \& Wiksel.

Funk, V.A.; Bayer, R.J.; Keeley, S.C.; Chan, R.; Watson, L.; Gemeinholzer, B.; Schilling, E.; Panero, J.L.; Baldwin, B.G.; Garcia-Jacas, N.; Susanna, A. \& Jansen, R.K. 2005. Everywhere but Antarctica: using a supertree to understand the diversity and distribution of the Compositae. Biologiske Skrifter 55: 343-374.

Hind, D.J.N. 2000. Two new species of Paralychnophora (Compositae: Vernonieae) from Bahia, Brazil. Kew Bulletin 55: 367-379.

Holmgren, P.K.; Holmgren, N.H. \& Bainett, L.G. 1990. Index Herbariorum. New York, New York Botanical Garden.

Jones, S.B. 1979. Synopsis and pollen morphology of Vernonia (Compositae: Vernonieae) in the New World. Rhodora 81: 425-447.

Jones, S.B. 1981. Synoptic classification and pollen morphology of Vernonia (Compositae: Vernonieae) in the Old World. Rhodora 83: 59-75.

Keeley, S.C. \& Jones, S.B. 1977. Taxonomic implications of external pollen morphology to Vernonia (Compositae) in the West Indies. American Journal of Botany 64: 576-584.

Keeley, S.C. \& Jones, S.B. 1979. Distribution of the pollen types in Vernonia (Vernonieae: Asteraceae). Systematic Botany 4: 195-202.

Keeley, S.C. \& Robinson, H. 2009. Vernonieae. In: Funk, V.A.; Susanna, A.; Stuessy, T.F.\& Bayer, R.J. (Eds). Systematics, evolution and biogeography of Compositae. Pp. 439-469. Wien: IAPT.

Kingham, D.L. 1976. A study of the pollen morphology of tropical african and certain other Vernonieae (Compositae), Kew Bulletin 31: 9-26.
Loeuille, B. 2011. Towards a phylogenetic classification of Lychnophorinae (Asteraceae). PhD Thesis. São Paulo, Universidade de São Paulo.

MacLeish, N.F.F. 1984. Eight new combinations in Vernonia (Compositae: Vernonieae). Systematic Botany 9: 133-136.

MacLeish, N.F.F. 1987. Revision of Eremanthus (Compositae: Vernonieae). Annals of the Missouri Botanical Garden 74: 265-290.

Melhem, T.S.; Cruz-Barros, M.A.V.; Corrêa, A.M.S.; Makino-Watanabe, H.; Silvestre-Capelato, M.S.F. \& Gonçalves-Esteves, V. 2003. Variabilidade polínica em plantas de Campos de Jordão (São Paulo, Brasil). Boletim do Instituto de Botânica, São Paulo 16: 9-104.

Mendonça, C.B.F. \& Gonçalves-Esteves, V. 2000. Morfologia polínica de algumas espécies da tribo Vernonieae (Compositae Giseke) ocorrentes na restinga da Carapebus, Rio de Janeiro. Hoehnea 27: 131-142.

Mendonça, C.B.F.; Esteves, R.L. \& Gonçalves-Esteves, V. 2007a Palinotaxonomia de espécies de Lepidaploa (Cass.) Cass. (VernoniinaeCompositae) ocorrentes no Sudeste do Brasil. Revista Brasileira de Botânica 30: 71-88.

Mendonça, C.B.F.; Gonçalves-Esteves, V.; Souza, M.A. \& Esteves, R.L. 2007b. Estudio polínico de Albertinia brasiliensis Spreng., de las especies de Cololobus H. Rob., Cyrtocymura H. Rob. y Dasyanthina serrata (Less.) H. Rob. (Vernoniinae-Compositae) que ocurren en el Sudeste de Brasil. Polibotánica 23: 77-92.

Mendonça, C.B.F., Souza, M.A., Gonçalves-Esteves, V. \& Esteves, R.L. 2007c. Palinotaxonomia de espécies de Chrysolaena H. Rob., Echinocoryne H. Rob. e Stenocephalum Sch. Bip. (VernonieaeCompositae). Acta Botanica Brasilica 21: 627-639.

Mendonça, C.B.F.; Gonçalves-Esteves, V.; Esteves, R.L.\& Nunes, A.D. 2009. Palynotaxonomy of Vernonanthura H. Rob. (Vernonieae, Asteraceae) species from Southeast Brazil. Revista Brasileira de Botânica 32: 647-662.

Mendonça, C.B.F.; Carrijo, T.T.; Esteves, R.L. \& Gonçalves-Esteves, V. 2010. Lessingianthus (Vernonieae-Asteraceae): generic and infrageneric relationships based on pollen morphology. Nordic Journal of Botany 28: $1-10$.

Peçanha, A.F.; Esteves, R.L. \& Gonçalves-Esteves, V. 2008. Palinotaxonomia de Albertinia brasiliensis Spreng., Eremanthus bicolor (DC.) Baker e Vanillosmopsis erythropappa (DC.) Sch. Bip. (CompositaeVernonieae). Acta Botanica Brasilica 22: 313-321.

Punt, W.; Hoen, P.P.; Blackmore, S.; Nilsson, S. \& Le Thomas, A. 2007. Glossary of pollen and spore terminology. Review of Palaeobotany and Palynology 143:1-81

Robinson, H. 1980. Notes on the Lychnophorine genera Chresta and Eremanthus (Vernonieae: Asteraceae). Phytologia 45: 89-100.

Robinson, H. 1987a. Studies in the Lepidaploa complex (Vernonieae: Asteraceae). I. The genus Stenocephalum Sch. Bip. Proceedings of the Biological Society of Washington 100: 578-583.

Robinson, H. 1987b. Studies in the Lepidaploa complex (Vernonieae: Asteraceae). II. A new genus Echinocoryne. Proceedings of the Biological Society of Washington 100: 584-589.

Robinson, H. 1987b. Studies in the Lepidaploa complex (Vernonieae: Asteraceae). III. Two new genera Cyrtocymura and Eirmocephala. Proceedings of the Biological Society of Washington 100: 844-855.

Robinson, H. 1988a. Studies in the Lepidaploa complex (Vernonieae: Asteraceae). IV. The new genus Lessingianthus. Proceedings of the Biological Society of Washington 101: 929-951.

Robinson, H. 1988b. Studies in the Lepidaploa complex (Vernonieae: Asteraceae). V. The new genus Chrysolaena. Proceedings of the Biological Society of Washington 101: 925-958.

Robinson, H. 1988c. Studies in the Lepidaploa complex (Vernonieae: Asteraceae). VI. A new genus Aynia. Proceedings of the Biological Society of Washington 101: 959-965.

Robinson, H. 1990. Studies in the Lepidaploa complex (Vernonieae: Asteraceae). VII. The new genus Lepidaploa. Proceedings of the Biological Society of Washington 103: 464-498.

Robinson, H. 1992. Notes on Lychnophorinae from Minas Gerais, Brazil, a synopsis of Lychnophoriopsis Schultz-Bip., and the new genera Anteremanthus and Minasia (Vernonieae: Asteraceae). Proceedings of the Biological Society of Washington 105: 640-652.

Robinson, H. 1997. The Paralychnophora group of Eremanthus (Vernonieae: Asteraceae). Rhodora 98: 85-93. 
Robinson, H. 1999. Generic and subtribal classification of American Vernonieae. Smithsonian Contributions to Botany 89: 1-116.

Robinson, H. 2006/2007. Tribe Vernonieae. In J. Kadereit \& C. Jeffrey (Eds.), The families and genera of vascular plants. vol. 8. Asterales (pp. 165-192). Berlin, Springer.

Robinson, H. \& Kahn, B. 1986. Trinervate leaves, yellow flowers, tailed anthers, and pollen variation in Distephanus Cassini. Proceedings of the Biological Society of Washington 99: 493-501.

Salgado-Labouriau, M.L.; Vanzolini, P.E. \& Melhem, T.S. 1965. Variation of polar axes and equatorial diameters in pollen grains of two species of Cassia. Grana Palynologica 6: 166-176.
Salgado-Labouriau, M.L. 1973. Contribuição à palinologia dos cerrados Rio de Janeiro, Academia Brasileira de Ciências.

Skvarla, J.J.; DeVore, M.L. \& Chissoe, W.F. 2005. Lophate sculpturing of Vernonieae (Compositae) pollen. Review of Palaeobotany and Palynology 133: 51-68.

Stix, E. 1960. Pollenmorpholosgische untersuchungen na Compositen. Grana Palynologica 2: 41-114.

Wortley, A.H.; Funk, V.A.; Robinson, H.; Skvarla, J.J. \& Blackmore, S. 2007. A search for pollen morphological synapomorphies to classify rogue genera in Compositae (Asteraceae). Review of Palaeobotany and Palynology 146: 169-181.

Wortley, A.H.; Funk, V.A. \& Skvarla, J.J. 2008. Pollen and evolution of Arctotideae (Compositae). Botanical Review 74: 438-466. 